\title{
SPRings ConNect People and LandSCAPES - EnVironmental EduCation AND COOPERATION IN THE REgION LIBEREC-ZiTTAU
}

\author{
Tomáš Vitvar ${ }^{1}$; Matthias Kändler ${ }^{2}$; Jiří Šmída ${ }^{3}$; Dana Komínková ${ }^{1}$; \\ Kateřina Ženková Rudincová ${ }^{3}$; Emil Drápela $^{3}$; Kamil Zágoršek ${ }^{3}$; Lucie Součková ${ }^{1}$; \\ Kateřina Berchová ${ }^{1}$; Michal Bílý ${ }^{1}$; Hynek Böhm ${ }^{3}$ \\ ${ }^{1}$ Česká zemědělská univerzita v Praze, Faculty of Environmental Sciences, \\ Kamýcká 129, 16521 Praha, Czech Republic \\ ${ }^{2}$ Technische Universität Dresden, International Institute Zittau, \\ Chair of Environmental Biotechnology, \\ Markt 23, 02763 Zittau, Germany \\ ${ }^{3}$ Technická Univerzita v Liberci, Faculty of Science, Humanities and Education, \\ Department of Geography \\ Komenského 314/2, 46001 Liberec, Czech Republic \\ e-mail: ${ }^{1}$ vitvart@fzp.czu.cz; ${ }^{2}$ matthias.kaendler@tu-dresden.de; ${ }^{3}$ jiri.smida@tul.cz; \\ ${ }^{1}$ kominkovad@fzp.czu.cz; ${ }^{3}$ katerina.rudincova@tul.cz; ${ }^{3}$ emil.drapela@tul.cz; \\ ${ }^{3}$ kamil.zagorsek@tul.cz; ${ }^{1}$ souckoval@fzp.czu.cz; ${ }^{1}$ berchova@knc.czu.cz; ${ }^{1}$ bilym@fzp.czu.cz; \\ ${ }^{3}$ hynek.bohm@tul.cz
}

\begin{abstract}
This paper describes the trilateral transboundary project Prameny spojuji/Quellen verbinden launched in 2016 under the coordination of the Technical University of Liberec. The aim of the project is a complex hydrochemical, hydrobiological, hydrological, geological and human geographical assessment of a set of about 40 springs in the region Liberec - Zittau through educational and research networking of the partner universities. This region has considerably humid climatic environment reflected in a high number of springs, whose mutual multidisciplinary assessment has been largely missing. Preliminary example results at the Ploučnice spring reveal a calcium-bicarbonate water originating from the Bohemian Cretaceous Basin, with slightly elevated spring values of $\mathrm{Cd}$ and autumn values of $\mathrm{Pb}$ in the sediment. The spring ecosystem is characterized by seminature montane mixed forest, with presence of freshwater shrimp in the spring water. The Ploučnice spring is one of the most abundant springs in Central Europe with a good water quality, which has promoted the use of this water for drinking purposes around 1900, and until the 1960's for water energy in the nearby mills.
\end{abstract}

\section{Keywords}

Education; Environmental sciences; Springs; Chemistry; Biology; Transboundary region.

\section{Introduction}

Water has a vital importance for mankind; although it is a renewable resource, it is necessary to protect it and sustainably manage its use. Special attention should be given to possible sources of drinking water, namely groundwater and its surface discharges - springs. Hydrochemical analysis of spring water and in sediment delivers information about the quality of spring water and its interaction with surrounding rocks and soils. Studying biota in springs and their surroundings reveals the relations between water and living organisms in 
headwater areas. Finally, exploring the relationship of man to springs at his living place describes cultural aspects linked with the importance of water.

Focused on above mentioned topics, the project Prameny spojuji/Quellen verbinden has been created by researchers from the Technical University of Liberec, Czech University of Life Sciences and Technical University of Dresden in 2016. This three-year project aims to improve the skills of students of participating universities, to promote international research cooperation and implement educational activities. Hydrochemical, hydrobiological, hydrological and human geographical research of springs is an important instrument to achieve its objectives.

The abundant surface water and groundwater resources in the region Liberec-Zittau and its surroundings have been recently addressed by several transboundary projects [1], [2], [3]. These studies have dominantly addressed the groundwater and surface water hydrology and/or their links to the land use and human activities. A complex hydrochemical, hydrobiological, hydrological, geological and human geographical assessment at the transboundary scale has not yet been performed.

\section{$1 \quad$ Research Aim and Objectives}

This project is based on an assessment of about 40 selected springs in the transboundary Liberec-Zittau area. They were selected upon relevant available information and field prescreening of about 100 springs, which represent the variety of geological, hydrochemical, hydrological, hydrobiological and human geographical aspects of the study area. During the first project year, a research methodology was created and first results have been obtained. This paper presents the adopted methodology (Fig. 1) and addresses the preliminary results on the example of the Ploučnice spring. It is expected that this methodology will serve to future assessment of further springs in this area and also complement the environmental education in the transboundary region Liberec-Zittau. Complete results will be published at the project end in 2019.

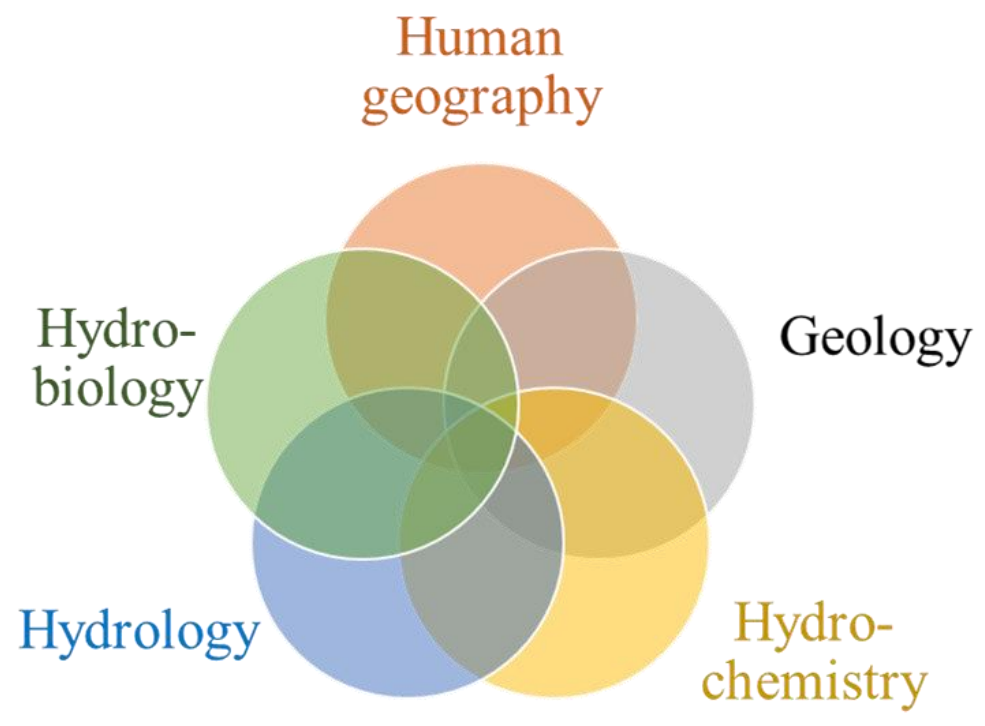

Source: Own

Fig. 1: Scheme of the methodology of the project Prameny spojuji/Quellen verbinden 


\subsection{Overview of the Area}

The project study area (Fig. 2) covers the transboundary zone on the borders between Czech Republic and Germany (Saxony). It is located in the districts Liberec, Ústí n.L. and Görlitz approximately between the cities of Liberec, Zittau, Rumburk, Nový Bor, Český Dub and Turnov. The area largely belongs to the Western Sudetes geomorphological region (in Czech: Krkonošská oblast, in German: Westsudeten) with major ranges Jizera Mountains (Jizerské hory - Isergebirge), Lusatian Mountains (Lužické hory - Lausitzer Gebirge) with the Saxonian part Zittau Mountains (Zittauer Gebirge), Lusatian Hills (Šlluknovská pahorkatina Lausitzer Bergland), Ještěd-Kozákov-Ridge (Ještědsko-Kozákovský hřbet - JeschkenKosakow-Kamm), and major sedimentary basins around Liberec and Zittau: the multilayered Bohemian Cretaceous Basin (Česká křídová pánev - Böhmisches Kreidebecken) and tertiary Zittau Basin (Žitavská pánev - Zittauer Becken). The area is traversed by the main European water divide between the Baltic Sea and Northern Sea watersheds and drained by major rivers Neisse, Mandau and Ploučnice. The climate of the area includes temperate and cold humid types with increased continentalism in the Zittau and Bohemian Cretaceous Basins. The longterm annual precipitation amount varies between approximately $1400 \mathrm{~mm}$ in the higher elevations of the mountains and $640 \mathrm{~mm}$ in the lowlands, with precipitation maxima in July and August [2]. High intense rainfall occurs frequently during spring and summer. The Jizera Mountains are characterized by snow cover lasting up to 160 days/year. The mean annual temperature varies between $8{ }^{\circ} \mathrm{C}$ in the lowlands and $5{ }^{\circ} \mathrm{C}$ in the mountains [4]. The all-time maximum daily precipitation amount at the territory of the Czech Republic (345 $\mathrm{mm}$ ) was measured in the central part of the Jizera Mountains.

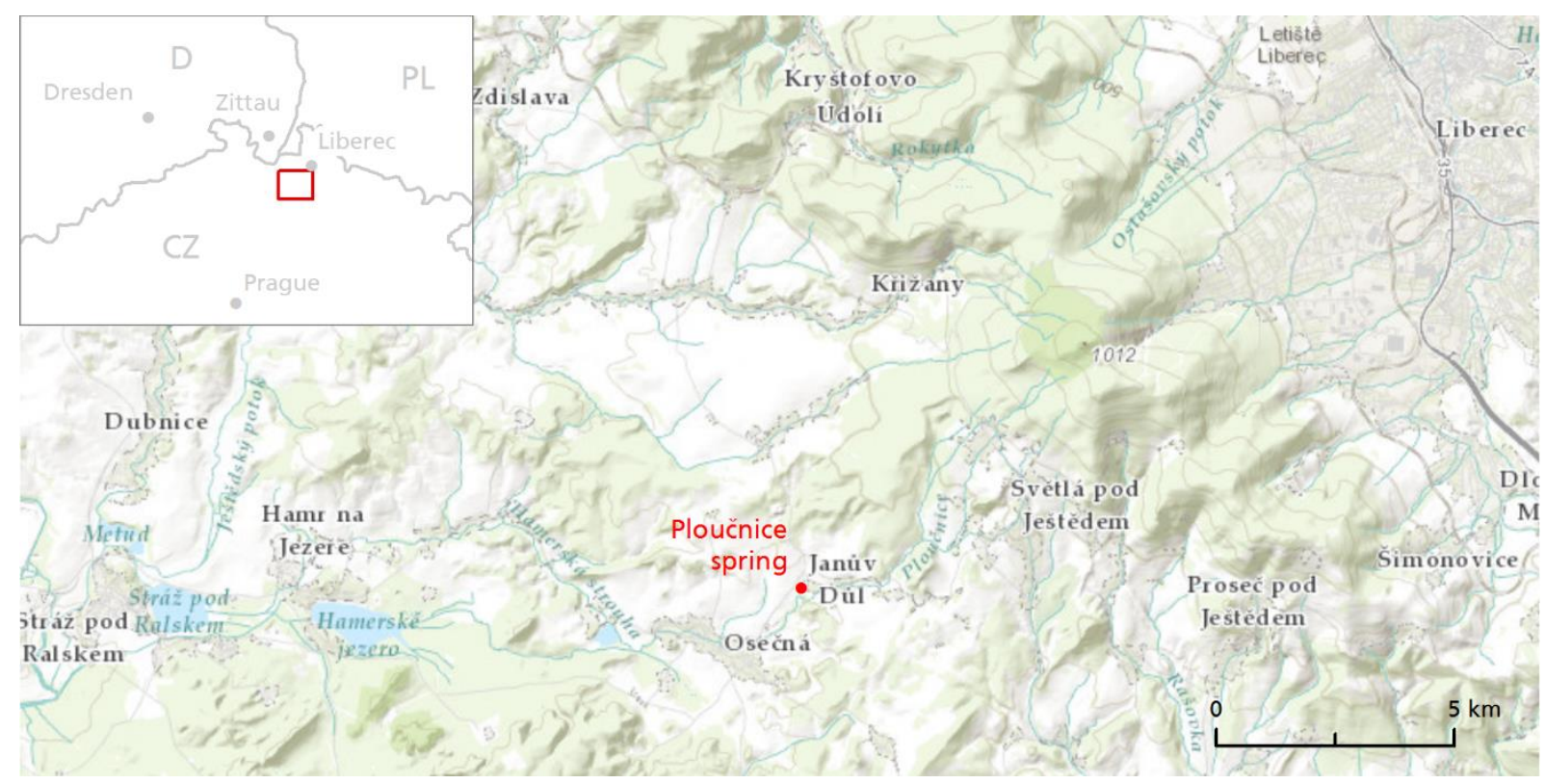

Source: Own data, basemap: ESRI

Fig. 2: Location of Ploučnice spring within the transboundary study area

The complex geological structure of the area is dominated by granites and granodiorites in the Jizera Mountains, by basaltoid volcanic in the Lusatian Mountains and Lusatian Hills, by metamorphic rocks of Ještěd-Kozákov-Ridge, by sandstones in the Zittau Mountains, and by Cretaceous sandstones to claystones in the Bohemian Cretaceous Basin. The crystalline and sedimentary formations are divided by the Lusatian fault. Basaltic and phonolitic hilltops are mostly present in the western part, whereas the lowlands in the Zittau and Liberec basins are 
dominated by Quaternary loess. Major aquifers in the area with extended stream-aquifer communication are formed in Cretaceous sandstones southbound from the Lusatian fault. These aquifers consist of a lower Cenomanian layer with overlying layers from Turonian and Coniacian age [5].

The soils have a range of properties, particularly with respect to runoff formation, erosion, solute transport and water storage capacity [6]. While the soils on mountainous hill slopes are mostly shallow, often skeleton-rich dystric cambisols, podzols and leptosols with low storage capacities, the valleys are filled by organosols that release humic and fulvic acids. The agricultural soils are mostly luvisols and stagnic luvisols with a high silt content and a low infiltration rate. They are partly affected by poorly drained horizons. Luvisols are easily erodible and contribute to the suspended load in the rivers. The lowland flood plains are typically covered by gleysols [2]. The land use differs according to the soil types. While the mountainous areas are dominated by spruce forests, the fertile soils in the lowlands are agriculturally exploited. Substantial parts of the Jizera Mountains and Lusatian Mountains in the Czech Republic as well as the Zittau Mountains in Germany were declared as nature protection zones.

\subsection{Flora and Fauna}

Vegetation characteristics of the spring surroundings were described using two methods: biotope description and fytocenological relevés. In the field, the main biotope types were identified in a circle of about $100 \mathrm{~m}^{2}$ that was delimited around the spring [7]. The dominant plant species in the identified biotopes were determined in each vegetation layer (tree, shrub and herb layers). The tree individuals were also recorded. The identified semi-natural types of biotopes became subject of a more detailed characteristic, using the fytocenological relevés approach (Br. - Bl. scale, [8]). This approach determines the type of vegetation using the fytocenological system. The vegetation type will serve for evaluation of the anthropogenic influence to spring surroundings.

Benthic invertebrates represent the most important animals in springs. Whereas meiofauna (benthic animals under $0.5 \mathrm{~mm}$ ) is observable by a microscope only, macroinvertebrates (benthic animals above $0.5 \mathrm{~mm}$ [9]) are visible to the naked eye and can be observed by a visitor of a spring. Considering the aim of the project, macroinvertebrates were selected as the organisms group representing a biota of the studied springs.

Macroinvertebrate samples were collected twice a year by a quantitative method. A perpendicularly embed plastic tube (diameter of $12 \mathrm{~cm}$, length of $20 \mathrm{~cm}$ ) was used for a demarcation and a cutting out of a representative spring bottom area. A surface layer of sediment was mined from the tube using a small ladle. A volume of a subsample was $400 \mathrm{~cm}^{3}$ of the bottom sediment. Six of such subsamples were carried out at every sampling date, covering different types of the bottom of the spring (mud, sand, gravel, organic sediments). These 6 subsamples were merged into one sample, representing one spring at one date.

Yet in field, the sample was sieved over a net of $0.5 \mathrm{~mm}$ to eliminate a fine substrate and reduce the sample volume. The sample was then placed in shallow bowls. Visible invertebrates were selected, saved in a small separate container and fixed by $70 \%$ ethanol. Only flatworms (Turbellaria) were saved alive in a small amount of spring water, because their determination needs a native form. All the remained material was saved in 11 plastic containers and preserved by $70 \%$ ethanol.

In the CULS laboratory, samples were sorted using a stereomicroscope. Macroinvertebrates unnoticed in the field were selected and main taxonomical groups and species were determined. 


\subsection{Chemistry}

Water samples for hydrochemical analysis were collected approximately once a month in 250ml plastic bottles (PE) - one for cations, one for anions and one for bicarbonate titration. On-site $\mathrm{pH}$-value and dissolved oxygen and electrical conductivity (EC) were measured using a Multimeter (WTW Multi 3430). Redox-potential was measured by a WTW pH 320. Where possible, discharge of the spring was measured by the "Bucket and Stopwatch method" [10].

Water samples were analysed in the TUD-IHI laboratory in Zittau for major ions $\left(\mathrm{NO}_{3}{ }^{-}, \mathrm{SO}_{4}{ }^{2-}, \mathrm{Cl}^{-}, \mathrm{PO}_{4}{ }^{3-}\right)$ by Ion Chromatograph (Dionex ICS-1100) and selected elements (e.g. $\mathrm{Ca}, \mathrm{Mg}, \mathrm{Fe}, \mathrm{Al}, \mathrm{K}, \mathrm{U}, \mathrm{As}$ ) by inductively coupled plasma with optical emission spectrometry (ICP-OES, PerkinElmer) according to DIN EN ISO 11885 (www.iso.org), and inductively coupled plasma mass spectrometry (ICP-MS, PerkinElmer) according to DIN EN ISO 17294-2 (www.iso.org) depending on their concentration. Bicarbonate concentration was carried out using titration with $\mathrm{HCl}$.

The data interpretation was carried out using software package Diagrammes [11]. The interpretation included the control of the ionic balance (equal sum of major anions and cations), determination of hydrochemical water types and data plotting in the form of particular hydrochemical plots.

The sampling of sediment in the springs was carried out twice a year (spring, autumn). Sediment samples were collected in plastic containers and frozen upon the return to laboratory. In the laboratory, the seamples were further processed by lyophilisation (freezedrying), homogenisation, sieving and microwave decomposition. After the decomposition the concentrations of metals in the samples were analyzed in the CULS laboratory by use of spectrometers FAAS a GTAAS (Agilent Technologies).

\subsection{Human Geography and GIS}

The human geographic dimension of the assessment of springs deserves attention since springs have been used by people for several reasons: (1) spring water has been used for drinking and cattle and plant watering; (2) people took care of the springs since they were sources of drinking water; (3) springs were used as meeting places; (4) water from particular springs was sometimes believed to have a healing effect.

In the presented project, springs are evaluated from the human geography perspective based on their use in selected historical eras: (1) industrialization of the Liberec-Zittau region until 1918; (2) era between 1918 and 1945; (3) period immediately after the expulsion of Sudeten Germans; (4) era of collectivisation (1950s); (5) era of mass suburbanization (1990s); (6) current era. There is an assumption that after 1945 the usage of springs changed significantly because of the expulsion of German population from the most of the Czech part of the selected territory and resettlement of the Czech population from inland. Consequently, also the toponymy and local names changed significantly, especially after 1945. In some cases, there was only a translation of the original German name to Czech, in others, new original Czech names were created or the newcomers brought the toponymy with them from their original homes. Toponymy is a constituent part of the cultural landscape since it is an expression of the creation of identities [12]. For this reason, the analysis of toponymy is an additional part of the springs' research. In addition to the official place names also local names, names used by the local residents themselves, are also subjects of the analysis. They are collected and examined using the method of mental mapping in particular, where the specific local names are identified by local population on the large-scale maps. 
The primary method of the data collecting for the analysis of springs forming the human geography perspective is semi-structured interviewing. It means that the interview schedule is prepared with fully worded questions, but the respondents are given enough space to explain their stances and postures freely [13]. During the first round of interviews, the mayors of selected villages of particular interest were interviewed. The method of semi-structured interviewing was combined with oral history [14], aimed at identifying the stories and legends connected to the springs. The major effort in this research phase is to find witnesses of different historical eras with the aim to find out how the springs were used in a defined time period and to collect various stories and legends particular springs are surrounded by. Based on these findings it is possible to identify the local identities which have been created thanks to collective memory and shared meaning of a place or genius loci [15]. Springs became part of the local legends and fairy tales; sometimes they are connected to the existence of supernatural beings and rituals such as "opening of the wells".

These primary methods are complemented by the archival research of historical documents and analysis of old maps, since there is an assumption that if the springs are located on old maps they were widely used in the past. Therefore, the basic objective of this method is to identify the existing springs on the old maps with the critical evaluation of the particular sources and the historical era they were produced in.

Several GIS-based tools are being prepared within the framework of the project. A prominent example is the simplified geological map 1:100.000 covering both the Czech and German parts of the study area. The map was constructed using ArcGIS on the ESRI basemap platform from the following sources: mainly geological map of Czech 1:50 000 from geology.cz (http://mapy.geology.cz/geocr_50/), detailed Geological Map of the area Lausitz-

Jizera-Karkonosze, and German geological map (Geologische Übersichtskarte der Bundesrepublik Deutschland 1:200.000 (GÜK200) - CC 5550 Görlitz).

\section{$2 \quad$ Results and Discussion}

This chapter describes preliminary results on the example of the Ploučnice spring (Fig. 3).

The Ploučnice spring is one of the best-known springs in the Podještědí (Lower Ještěd) region. It has already been marked on old maps, such as on the map sheet Turnov of the historical mapping of 1951. Its original name in German language was "Polzenquelle" and the current name "Pramen Ploučnice" is a literal translation from German. An interesting fact is that this spring, called "Pramen Ploučnice" is not the real source of the river Ploučnice, but it got its name because of its largest discharge level (Interview with the mayor of Janův Důl, Jan Mašek, 26. 7. 2016). The spring has a form of a small lake with several groundwater inflows (Fig. 3). 


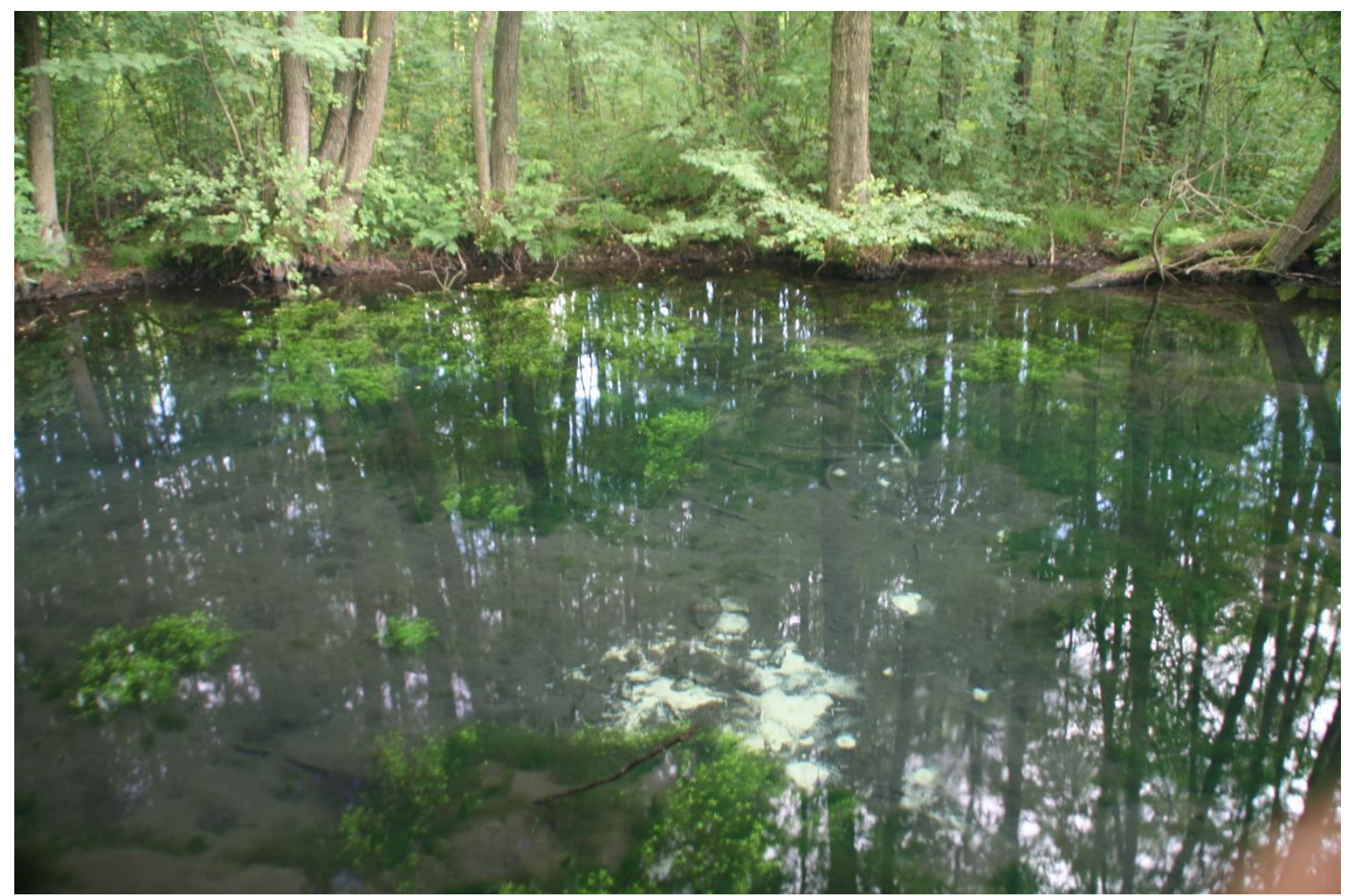

Source: Photo by M. Kändler

Fig. 3: Photo of the Ploučnice spring (June $22^{\text {nd }} 2016$ )

The Ploučnice spring is situated in the Bohemian Cretaceous Basin, in the valley between Osečná and Janův Důl. Majority of the area around the valley is covered by marine sand to fine grained conglomerate consisting of small clasts of quartz of Turonian age belonging to Jizera Formation. The sand is partially lithified, partially cross-bedded, indicating the high energy sedimentation environment. However, the valley itself is filled by quaternary sediments, mainly loess from last glacial period (Upper Pleistocene) with intercalations of fine quartz clasts and with carbonate filling. The place surrounding the spring is formed by sub recent (quaternary) fluvial clay, sand and gravel. The whole area is fragile, deformed from northeast to southwest direction, which is indicated by short tectonic faults. Part of the faults was rejuvenated during Tertiary (Eocene to Oligocene) and filled by dispersed alkaline volcanic veins. The nearest basaltoid vent is situated about $1 \mathrm{~km}$ southwest from the Ploučnice spring [5].

The vegetation around the Ploučnice spring is characterized by a seminatural mixed montane sycamore-beech forest with dominant Acer pseudoplatanus, Fagus sylvatica and sporadically mixed with Alnus incana. The scrub layer is almost missing, whereas the herb layer is dominated by forest species such as Athyrium filix-femina, Dryopteris filix-mas, Festuca altissima, Galium odoratum, Gymnocarpium dryopteris, Mercurialis perennis, Oxalis acetosella and Vaccinium myrthillus. The character of the vegetation reveals a low human influence and almost no anthropogenic pollution of the closest spring surroundings.

Freshwater shrimp (Gammarus fossarum) was the absolutely most abundant macroinvertebrate species across the observed set of 40 localities, including the Ploučnice spring. In some springs, this animal represented over $90 \%$ of the sampled individuals. It is in accord with a wide occurrence of this species and its high ecological adaptability [16]. This species belongs to a typical spring fauna; however, generally it inhabits a large scale of running waters. 
The second most abundant group of organisms Caddisflies (Trichoptera) also represents a common spring taxa. Stoneflies (Plecoptera) occurred in a lesser extent. However, one season is too short for an evaluation of occurrence of these animal groups; more comprehensive results are expected upon the complete 3-year survey.

Fig. 4 shows the concentrations of major ions $\left(\mathrm{NO}_{3}{ }^{-}, \mathrm{SO}_{4}{ }^{2-}, \mathrm{Cl}^{-}, \mathrm{HCO}_{3}{ }^{-}, \mathrm{Ca}^{2+}, \mathrm{Mg}^{2+}, \mathrm{Na}^{+}, \mathrm{K}^{+}\right)$ in sample water during five sampling turns at the Ploučnice spring in 2016/2017. This water has a rather moderate mineralization (average conductivity is $242 \mu \mathrm{S} / \mathrm{cm}$ ), revealing waterrock interactions of the spring water prior to emerging on the surface. The average $\mathrm{pH}$ is 7.21 and the average dissolved oxygen concentration is $8.6 \mathrm{mg} / \mathrm{l}$. The Piper and Stiff diagrams on Fig. 4 demonstrates that the dominant cation is $\mathrm{Ca}^{2+}$ and the dominant anion is HCO3-. Less abundant cation is the sum of $\mathrm{Na}^{+}$and $\mathrm{K}^{+}$and the less abundant anion is $\mathrm{SO}_{4}{ }^{2-} \cdot \mathrm{Mg}^{2+}$ and the sum of $\mathrm{NO}_{3}{ }^{-}$and $\mathrm{Cl}^{-}$are present only marginally. This is a typical pristine water type originating in carbonate rocks, with potential of drinking water use.
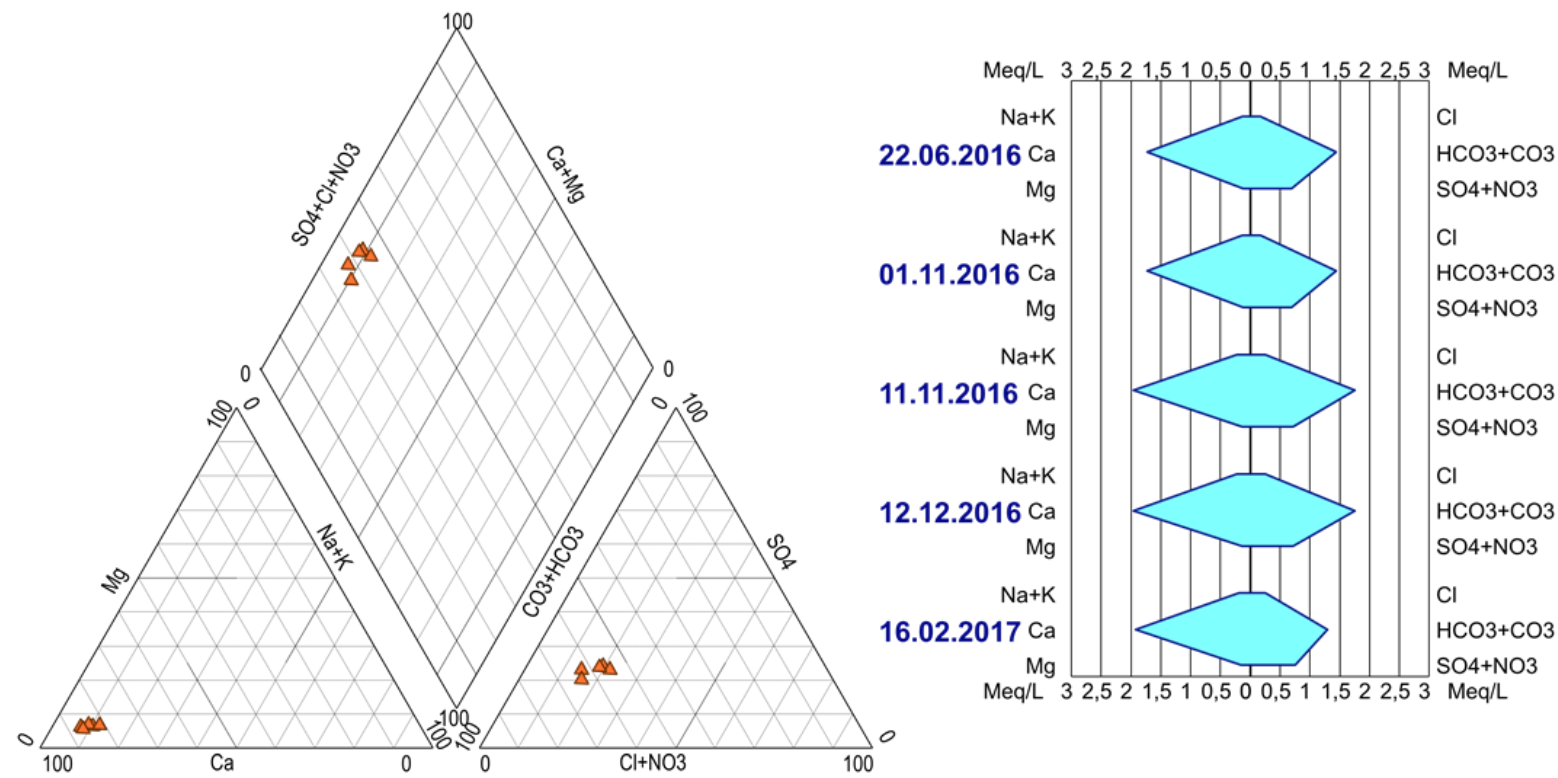

Source: Diagrammes software [9], own data

Fig. 4: Piper (left) and Stiff diagrams (right) of 5 water samples from the Ploučnice spring

Fig. 5 shows the concentrations of four toxic metals in the sediment of the Ploučnice spring, analysed in four sediment fractions $(\leq 0.061 \mathrm{~mm}, 0.061-0.206 \mathrm{~mm}, 0.206-0.609 \mathrm{~mm}$ and $>0.609 \mathrm{~mm}$ ). Whereas $\mathrm{Cu}, \mathrm{Zn}$, and $\mathrm{Cd}$ showed higher concentrations in the spring period samples, the $\mathrm{Pb}$ concentrations were higher in the autumn. The spring concentration of $\mathrm{Cd}$ are very close to the environmental quality standard (EQS) of the USEPA $\left(0.99 \mathrm{mg} \cdot \mathrm{kg}^{-1}\right)$. The measured higher autumn concentration of $\mathrm{Pb}$ in the fraction $>0.609 \mathrm{~mm}$ have exceeded the EQS of USEPA $\left(35.8 \mathrm{mg} \cdot \mathrm{kg}^{-1}\right)$. The concentrations of $\mathrm{Zn}$ and $\mathrm{Cu}$ remained below the EQS. 

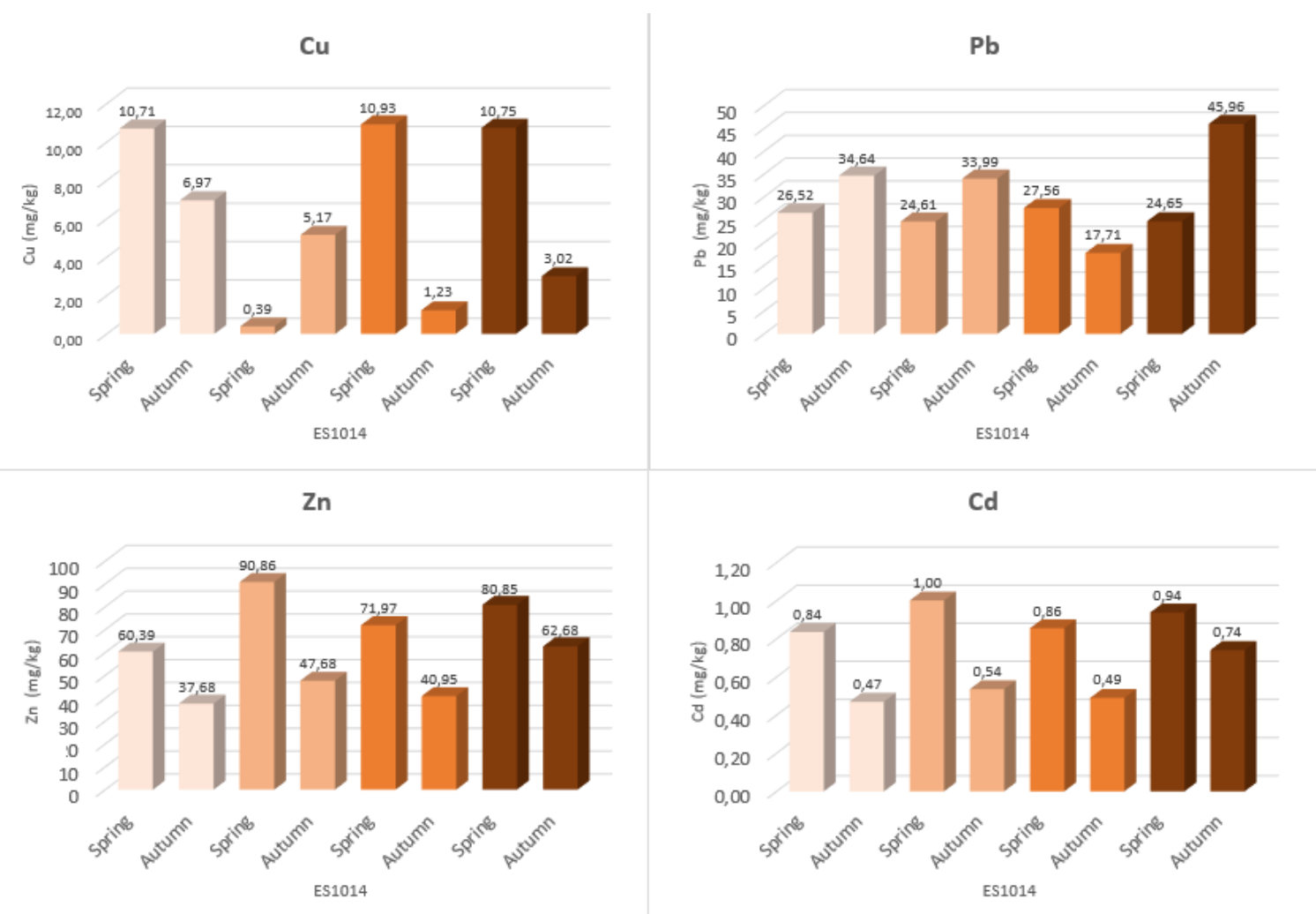

Source: Own data

Fig. 5: Concentrations of selected metals $(\mathrm{Cu}, \mathrm{Pb}, \mathrm{Zn}, \mathrm{Cd})$ in the sediment of the Ploučnice spring. Results in the fractions $\leq 0.061 \mathrm{~mm}, 0.061-0.206 \mathrm{~mm}, 0.206-0.609 \mathrm{~mm}$, and $>0.609 \mathrm{~mm}$ are depicted.

The Ploučnice spring has been widely used in the past. Nowadays, it is an interesting tourist point in this area. In the historical era, until approximately 1955 the Ploučnice spring was used to energy production because of its high level of discharge. There were many water mills built and during industrialization some of these mills were rebuilt to water turbines. One of the most important mills which were built nearby the spring is Jenišovský mill. After finishing the production of water energy from the spring, there was an intent to use the water form spring for production of soda water. This plan was, however, has been rejected by the local people since they were afraid that collection of water for this purpose would cause its scarcity [19]. An additional way of using the water from the Ploučnice spring was the creation of water supply around 1900. It consisted of a wooden pipe leading to the square where people used to scoop water from the fountain. These water pipes were not cleaned and maintained later so the usage of this water supply came to an end [19]. Currently, the water from spring is not being used for any purpose but the spring itself is maintained by the municipality of Osečná.

The Ploučnice spring is riddled with several legends. Some of them are based on the belief in the existence of supernatural beings; others are connected to the character of the spring itself. Probably the best-known of them, and mentioned in both interviews used in this brief study is a legend about the peasant who drove up to the spring with horses harnessed to a fully loaded carriage; and since the spring was very deep he got drown in it [19], [20]. Besides this legend, the respondents also mentioned the story about two children who wanted to swim in the spring but got drown because they did not estimate the depth of the spring properly, and the water was too cold [19], [20]. 
Concerning the supernatural beings, there is a vast amount of legends about watermen living by the spring. According to one of them, for example, there was a wicked waterman who drowned everybody who tried to poach in his water [17]. Another set of legends tells the stories about will-o'-the-wisps that attracted pilgrims to the water. Will-o'-the-wisps, however, are not only portrayed negatively, they also saved the life of one peasant by taking him out of the woods [18].

\section{Conclusion}

The project Prameny spojuji/Quellen verbinden has accumulated a considerable amount of data from all participating disciplines, revealing a potential of a complex interdisciplinary assessment of this type of water resource at the transboundary scale. The survey of assessed 40 springs showed that water, sediment and biota in the spring ecosystems in the target region reflect a variety of geological, hydrochemical and hydrobiological settings as well as cultural and historical patterns. The field research on the springs will continue over this year, complementing the preliminary results from the last year and also including assessment of some new springs that have been pre-screened to potentially deliver useful information for all participating disciplines.

\section{Acknowledgements}

The described project is funded by the programme Interreg VA SN-CZ 2014-2020, No. 101.002.497.391. The authors thank all the Bachelor, Master and Ph.D. students and technicians of the partner universities for their support of data collection and analysis as well as the local authorities for collaboration on the interviews.

\section{Literature}

[1] VÚV TGM, v.v.i.; LfULG (M.Kalinová and A.-K. Böhm, eds): Zdroje podzemnich vod na česko-saském pomezí. II. Oblast Petrovice-Lückendorf-Jonsdorf-Oybin. Výzkumný ústav vodohospodářský T. G. Masaryka, v.v.i., Praha, 2014. ISBN 978-80-87402-31-3.

[2] KÄNDLER, M.; BLECHINGER, K.; SEIDLER, C.; PAVLŮ, V.; ŠANDA, M.; DOSTÁL, T.; KRÁSA, J.; VITVAR, T.; ŠTICH, M.: Impact of land use on water quality in the upper Nisa catchment in the Czech Republic and in Germany. Science of the Total Environment. DOI: 10.1016/j.scitotenv.2016.10.221

[3] ŠANDA, M.; SEDLMAIEROVÁ, P.; VITVAR, T.; SEIDLER, C.; KÄNDLER, M.; JANKOVEC, J.; KULASOVÁ, A.; PAŠKA, F.: Pre-event water contributions and streamwater residence times in different land use settings of the transboundary Lužická Nisa catchment. Journal of Hydrology and Hydromechanics. DOI: 10.1515/johh-2017$\underline{0003}$

[4] ŠANDA, M.; VITVAR, T.; KULASOVÁ, A.; JANKOVEC, J.; CÍSLEROVÁ, M.: Run-off formation in a humid, temperate headwater catchment using a combined hydrological, hydrochemical and isotopic approach (Jizera Mountains, Czech Republic). Hydrological Processes. DOI: 10.1002/hyp.9847

[5] ULIČNÝ, D.: Depositional systems and sequence stratigraphy of coarse-grained deltas in a shallow-marine, strike-slip setting: the Bohemian Cretaceous Basin, Czech Republic. Sedimentology. DOI: 10.1046/j.1365-3091.2001.00381.x

[6] KÄNDLER, M.; SEIDLER, C.: Hydrochemical load in a small river following heavy rain events. Folia Geographica ser. Geographica-Physica. 2009, Vol. XL (40), pp. 2732. ISSN 0071-6715. 
[7] CHYTRÝ, M.; KUČERA, T.; KOČÍ, M. (eds.): Katalog biotopů České republiky. Agentura ochrany prírody a krajiny ČR, 2001, 307 p. ISBN 80-86064-55-7.

[8] ELLENBERG H.: Zeigerverte der Gefässpflanzen Mitteleuropas. Scripta Geobotanica. 1991, Vol. 18, pp. 1-248.

[9] KOKEŠ, J.; NĚMEJCOVÁ, D.: Metodika odběru a zpracování vzorků makrozoobentosu tekoucich vod metodou PERLA. [online]. 2006. [accessed 2017-0404]. Available from http://www.mzp.cz/C1257458002F0DC7/cz/prehled_akceptovanych_metodik_tekoucic h_vod/\$FILE/OOV-MAKROZOOBENTOS\%20\%20BRODITELN\%C3\%89 tekouci\%20vody-20130129.pdf

[10] MICHAUD, J.P.; WIERENGA, M.: Estimating discharge and stream flows. A guide for sand and gravel operators. [online]. 2005. [accessed 2017-04-04]. Available from WWW: https://fortress.wa.gov/ecy/publications/publications/0510070.pdf

[11] SIMLER, R. 2017. Diagrammes: Logiciel d'hydrochimie. Version 6.5.1. [online]. France, University of Avignon, 2017. 2017. [accessed 2017-04-04]. Available from WWW: http://www.lha.univ-avignon.fr/LHA-Logiciels.htm

[12] DAVID, J.; MÁCHA, P.: Názvy míst. Pamět', identita, kulturní dědictví. Host Publishing and Ostravská univerzita, Brno, 2014. ISBN 978-80-7464-503-7.

[13] DUNN, K.: Interviewing. In: Hay, I. (ed.), Qualitative Research Methods in Human Geography. Oxford University Press, 2005, pp. 79-105. ISBN 978-0-19-555079-5.

[14] GEORGE, K.; STRATFORD, E.: Oral History and Human Geography. In: Hay, I. (ed.), Qualitative Research Methods in Human Geography. Oxford University Press, 2005, pp. 106-115.

[15] BIRD, S. E.: It Makes Sense to Us: Cultural Identity in Local Legends of Place. Journal of Contemporary ethnography. 2002, Vol. 31, Issue 5, pp. 519-547. ISSN 0891-2416.

[16] SLÁDEČEK, V.; SLÁDEČKOVÁ, A.: Atlas vodních organismů se žretelem na vodárenství, povrchové vody a čistírny odpadnich vod: 2. dill: Konzumenti. ČVVS, Praha, 1997. ISBN 80-02-01101-5.

[17] ŘEHÁČEK, M.: Vyprávění o strašidlech, př́zracích a podivných úkazech nejsevernějších Čech. Kalendár̆ Liberecka, Liberec, 1997. ISBN 80-238-3847-4.

[18] ŘEHÁČEK, M.: Pramen Ploučnice: $K$ jezirku hastrmanů a bludiček. [online]. Český rozhlas Liberec, 2016-11-21. [accessed 2017-03-23]. Available from WWW: http://www.rozhlas.cz/liberec/krizemkrajem/_zprava/pramen-ploucnice-k-jezirkuhastrmanu-a-bludicek--1671334

[19] Interview with the mayor of Osečná, Jiří Hauzer, 2016-07-26.

[20] Interview with the mayor of Janův Důl, Jan Mašek, 2016-07-26.

RNDr. Tomáš Vitvar; Dr. Matthias Kändler; Mgr. Jiří Šmída, Ph.D.; prof. RNDr. Dana Komínková, Ph.D.; Mgr. Kateřina Ženková Rudincová, Ph.D.; Mgr. Emil Drápela, Ph.D.; doc. RNDr. Kamil Zágoršek, Ph.D.; Ing. Lucie Součková; doc. Ing. Kateřina Berchová, Ph.D.; Mgr. Michal Bílý, Ph.D.; Mgr. Hynek Böhm, Ph.D. 


\section{PRAMENY SPOJUJÍ KRAJINY A STÁTY - ENVIRONMENTÁLNÍ VZDĚLÁVÁNÍ A KOOPERACE V REGIONU LIBEREC-ZITTAU}

Tento článek popisuje trojstranný přeshraniční project Prameny spojují/Quellen verbinden, zahájený v roce 2016 a koordinovaný Technickou univerzitou v Liberci. Záměrem projektu je komplexní hydrochemické, hydrobiologické, hydrologické, geologické a humánně geografické zhodnocení souboru asi 40 pramenů v oblasti Liberec-Zittau, a to cestou vzdělávací a výzkumné spolupráce partnerských univerzit. Vlhké podnebí této oblasti se promítá do značného množství pramenů, jejichž společné multidisciplinární hodnocení nebylo dosud provedeno. Předběžné výsledky na př́kladě pramenu Ploučnice ukazují vápenatohydrogenuhličitanovou vodu pocházející z České křrídové pánve, přičemž v pramenném ekosystému jsou př́tomny sladkovodní různonožci. Pramen Ploučnice je jeden z nejvydatnějších pramenů ve střední Evropě s dobrou kvalitou vody, což kolem roku 1900 podporovalo její využití jako pitnou vodu a do 60. let minulého století využití jako vodní energii pro blízké mlýny.

\section{QUELLEN VERBINDEN LANDSCHAFTSEINHEITEN UND STAATEN - UMWELTBILDUNG UND KOOPERATION IN DER REGION LIBEREC-ZITTAU}

Dieser Artikel beschreibt das im Jahre 2016 begonnene und durch die Technische Universität Liberec koordinierte trilaterale grenzüberschreitende Projekt Prameny spojuji/Quellen verbinden. Das Ziel des Projektes ist eine komplexe hydrochemische, hydrobiologische, hydrologische, geologische und humangeographische Beurteilung von ungefähr 40 Quellen in

der Region Liberec-Zittau durch Bildungs- und Forschungskooperation der Partneruniversitäten. Diese Region ist durch ein feuchtes Klima mit zahlreichen Quellen charakterisiert, deren gemeinsame multidisziplinäre Betrachtung bisher nicht durchgeführt wurde. Vorläufige Ergebnisse am Beispiel der Ploučnice-Quelle zeigen auf ein KalziumHydrogenkarbonathaltiges Wasser des Böhmischen Kreidebeckens, mit Vorkommen von Süßwasserkrebsen in dem Quellökosystem. Die Ploučnice-Quelle gehört zu den ergiebigsten Quellen Mitteleuropas mit guter Wasserqualität; dies führte um 1900 zur Nutzung als Trinkwasser sowie bis in die 60er Jahre des 20. Jahrhunderts zur Nutzung als Wasserenergie für die naheliegenden Mühlen.

\section{ŹRÓDŁA ŁĄCZĄ REGIONY I KRAJE - EDUKACJA ŚRODOWISKOWA I KOOPERACJA W REGIONIE LIBEREC-ZITTAU}

Niniejszy artykuł opisuje rozpoczęty w 2016 roku trójstronny transgraniczny projekt pn. Prameny spojují/ Źródła łączą, koordynowany przez Uniwersytet Techniczny w Libercu. Przedmiotem projektu jest kompleksowe hydrochemiczne, hydrobiologiczne, hydrologiczne, geologiczne i antropogeograficzne zbadanie około 40 źródeł znajdujących się w regionie Liberec-Zittau, realizowane $\mathrm{w}$ ramach współpracy uniwersytetów partnerskichw zakresie edukacji i badań naukowych. Region ten charakteryzuje się wilgotnym klimatem z licznymi źródłami, które do tej pory nie zostały jeszcze poddane wspólnym wielodyscyplinarnym badaniom. Wstępne wyniki, na przykładzie źródła Ploučnicy, wskazują na obecność wody wapienno-węglowodanowo-węglanowej pochodzącej z Czeskiej Niecki Kredowej, przy czym w źródliskowym ekosystemie występują obunogi słodkowodne. Źródło Ploučnicy zalicza się do najbardziej wydajnych źródeł w Europie środkowej charakteryzując się dobrą jakością wody; co doprowadziło około roku 1900 do jego wykorzystania jako źródła wody pitnej, a do lat 60. XX wieku do produkcji energii w okolicznych młynach. 